\title{
SORGHUM STORAGE AND PEST CONTROL AMONG FARMING HOUSEHOLDS IN KWARA STATE, NIGERIA
}

\author{
${ }^{1}$ Muhammad-Lawal A, ${ }^{2}$ Salau SA*, and ${ }^{1}$ Olawusi CO \\ ${ }^{1}$ Department of Agricultural Economics and Farm Management, Faculty of Agriculture, University \\ of Ilorin, Nigeria. \\ ${ }^{2}$ Department of Agricultural Economics and Extension Services, College of Agriculture, Kwara \\ State University, Malete, Nigeria.
}

Accepted: $23^{\text {rd }}$ September 2015

\begin{abstract}
This study was carried out to analyse the sorghum storage and pest control in Kwara State. A multi-stage sampling technique was used to select sample for the study. Descriptive statistics and logit regression analysis were the analytical tools employed to achieve the research objectives. The results showed that the respondents have an average age of 46 years with an average family size of 9 persons. They have an average storage experience of 14 years with the majority $(\mathbf{4 2 . 5 \%})$ were uneducated. The agro-chemicals mostly used by the respondents are Actellic liquid, Actellic dust and Phostoxin Tablet to prevent pest infestation and spoilage. The analysis showed that educational level, household size and access to credit having the t-values of $2.197,-3.075$ and 2.539 respectively were the significant factors explaining the usage of improved storage facilities in the study area. For effective pests and disease control through adequate access to pesticide and appropriate storage facilities, policies like loan schemes that would substantially improve households' access to use and acquisition of credits will facilitate the usage of improved storage techniques and consequently will enhance households' income.
\end{abstract}

Key words: Agrochemicals, sorghum, storage and improved techniques

\section{INTRODUCTION}

Nigeria is mainly an agrarian nation. The country is a major producer of some agricultural products (cocao, groundnuts, maize) and the leading producer and consumer of sorghum, cowpea and millet in the world (Werder and Manzo, 2002). Sorghum (Sorghum bicolor L. Moench) is one of the major cereal crops widely grown in Nigeria, and a very important staple food for the populace particularly in the Northern part of the country. According to Okpele, (2006) this crop is still one of the major sources of energy in the nutrition of both humans and livestock. It is the first most important cereal crops in Nigeria and is mainly used for food, animal feeds and making drinks (Ojo, 2000)

The increase in food demand-supply gap in Nigeria is attributable to the country's high population growth and high demand for her

*Corresponding author: talk2salaushehu@yahoo.com low price food items. This problem has become acute because the average crop yields for most of these agricultural products have been generally low from farmers' fields. Crops yields range between $500-800 \mathrm{~kg} / \mathrm{ha}$ for sorghum, maize, rice and millet (Sharma and Nwanze, 1997) and between $250-500 \mathrm{~kg} /$ ha for cowpea and cotton (Singh et al., 1997). There is therefore an urgent need to raise the productivity levels of these crops and so give remedy to food insecurity and poverty in Nigeria. Over the years, successive governments in Nigeria have initiated efforts aimed at raising the nation's agricultural production. However, several constraints have posed as challenges to these efforts. These constraints include crop losses due to storage pests, diseases, weeds, drought, weather and inadequate funding constraints.

The storage of agricultural products may be done for consumption at a future date or for economic reasons. Government may also store 
surplus agricultural products for price stabilization by releasing such crop reserves to the market in times of food scarcity. Despite the numerous advantages of crop storage, damage by storage pests especially the insect pests is the most important limiting factors to the efficient storage of agricultural products. In some instances, losses up to 30 to 70 percent have been recorded on stored food in the absence of efficient storage pests control measures (Dike, 1994). Postharvest loss is the degradation in both quantity and quality of a food production from harvest to consumption. Quality losses include those that affect the nutrient/caloric composition, the acceptability, and the edibility of a given product. These losses are generally more common in developed countries (Kader, 2002). Quantity losses refer to those that result in the loss of the amount of a product. Loss of quantity is more common in developing countries (Kitinoja and Gorny, 2010). For stored product pests cause damage to crops as they eat up portions of the produce leading to losses usually manifested by reduction in weight (Kumar and Okoronkwo, (1991). These pests also contaminate produce with fresh foreign materials.

Damage and losses to stored grains especially sorghum by insect pests is very severe, it has been estimated that about 75 percent of problem of storage losses is due to insect pests. The total estimated annual loss of grains to insect pests in Nigeria is about 20 percent of total production (Ajibola and Daramola, 1998). Storage pests cause direct and indirect damage to stored agricultural products. Direct damage are in form of weight loss, loss grade of grains, lowering of harvests market value, contamination and damage to storage structures and containers. Indirect damage on crops include: heating and moisture migration in silos and other storage structure like rhombus and cribs. Other indirect damages are spreading of moulds and spares throughout the grains mass and monetary expenses in terms of the purchasing pest control chemical. Recent report on assessment of stored products losses are few in literature and some of the ones available provide outdated data on a few products. For instance, it was reported a few decades ago that about 4 percent of the total annual production of sorghum or about 30,000 tonnes valued at over 30 million US dollars is lost annually to the sorghum brunched in Nigeria alone (Singh, 2000 ). Losses from weevil infestation were put at 50 percent for cereals on storage. Pest like rodent directly consumes food commodities stored by man. A single average sized rat may alone consume at least $500 \mathrm{~g}$ of grain per month (Appert, 1997). Partially consumed food may become inedible and in the use of seed, the germination capacity may be impaired. Rodent may be more economically important in bulk grain storage because they contaminate the commodity with their carcasses hair, feaces and urine (Evans, 2007). Appert (1997) also reported that birds damage stored products especially cereals by directly consuming them. Their economic importance is perhaps largely related to contamination of the grain with their droppings, feather or various materials.

Despite the adoption of the traditional and the improved ways of controlling storage pest losses for agricultural produces, the persistent post harvest losses for Sorghum is still on the increase. Efforts aimed at achieving viable crop storage are timely as such efforts would go a long way in alleviating the key problem facing agriculture in Nigeria. This study helps the policy makers in the area of agricultural storage pest control to come up with appropriate policy for agricultural food loss prevention. This study therefore describes the storage activities and highlights the determinants of the usage of improved storage techniques in the study area.

\section{MATERIALS AND METHOD}

The research work was carried out in Kwara state, Nigeria because the state is noted for sorghum production. The state lies between latitude $7^{\circ} 45 \mathrm{~N}$ and $9^{\circ} 30 \mathrm{~N}$ and longitudes $2^{\circ} 30 \mathrm{E}$ and $6^{\circ} 25 \mathrm{E}$ (Figure 1). According to the 2006 National Population Census report, the popula- 
tion of Kwara state stood at 2.73 million. Popular ethnic groups found in the state include; Yoruba, Fulani, Batunu, Nupe, Bokobanu and Gambari. Over 90 percent of the rural populace is involved in farming (Kwara ministry of Information, 2004). The favourable climate and the large expanse of land makes the state well suited for the cultivation of a wide variety of crops including cereals, tubers, legumes and vegetables like spinach, okra etc( kwara State Dairy, 2002). The state is classified into four agro ecological zones: A, B, C and D by the Kwara State Agricultural Development Project (KWADP). The classification is based on the ecology and administrative convenience.

Sorghum producing households and traders constitute the target population for the study. A three stage sampling procedure was em- ployed to select a representative sample for the study. The sampling is the KWADP Village listing. The first stage involved a random of 2 Local Government Areas (LGAs) from each of the four ADP zones resulting in 8 LGAs. This was followed by random selection of 2 villages from each of the selected LGAs making a total of 16 villages. In each of the selected villages 12 farming households were selected to make up a sample size of 192 . However, only 160 questionnaires were returned and analyzed.

\section{Variables and measurements used to achieve the research objectives}

The dependent variable (Y) usage of improved storage techniques takes the value of 1 if the household head was a user and 0 if otherwise. The common agro-chemicals used by

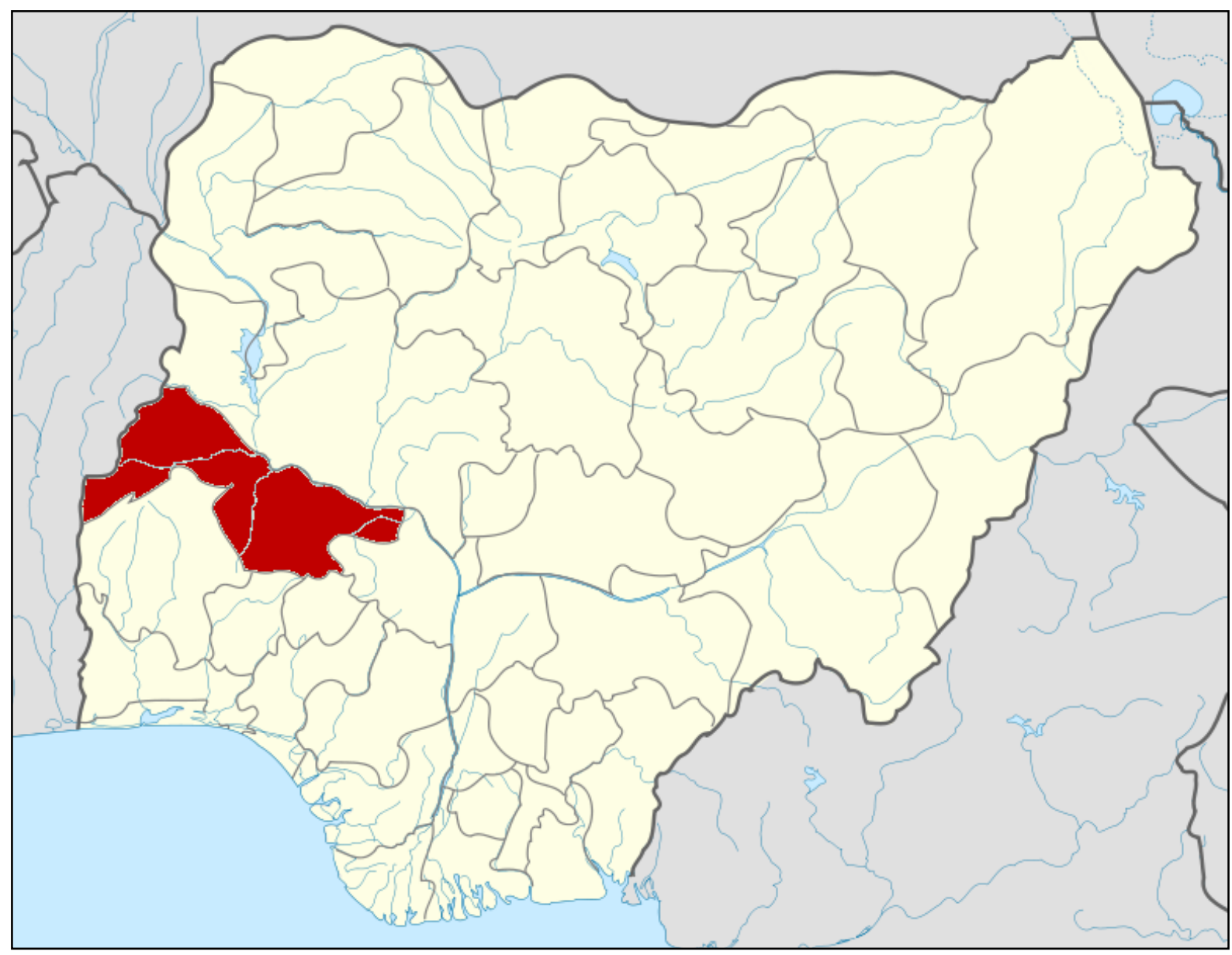

Figure 1: Map of Nigeria showing the location of Kwara State. 
the respondents are actellic liquid, actellic dust and phostoxin

Education of household head $\left(\mathrm{X}_{1}\right)$ was measured as the number of years of scholling of the household head. According to Babatunde et. al., (2007) education is a social capital, which could impact positively on a household's ability to take good and well-informed production and nutritional decision.

Dummy variable was used to capture whether or not the household head accept that pests are threat to the stored sorghum $\left(\mathrm{X}_{2}\right)$. It takes the value of 1 if yes and 0 if otherwise.

The size of the household $\left(\mathrm{X}_{3}\right)$ generally reflects the level of family labour available. This was based on the number of direct and dependants of the household.

In order to enhance the flow of credit services $\left(\mathrm{X}_{4}\right)$ to Nigerian rural areas, Government has, in the past, initiated a series of publiclyfinanced micro/rural credit programmes and policies targetted at the poor. It takes the value of 1 if the household head has access to credit and 0 if otherwise

Descriptive statistics such as frequency, percentages, mean and mode were used to analyze data gathered for different post harvest storage techniques available, the tool was also used to examine the socio economic characteristics of the households that store sorghum in the study areas and constraints faced in the usage of improved storage facilities.

The logit model was used to analyse factors influencing the decision to use improved storage techniques. The dependent variable is the usage of improved storage techniques by the respondents, which is one if yes, and zero otherwise. Following Maddala (1990) and Babcock et al (1995), the model specification gives rise to a system of two probabilities as:

$\operatorname{Prob}\left(Y_{i=j}\right)=\sum^{2} \frac{e^{\beta j X i}}{e^{\beta k N i}}$
Where $\mathrm{J}=0$ or 1

Expanding equation 1:

$\operatorname{Pr} o b\left(Y_{i}=j\right)=\frac{e^{n_{j} x_{i}}}{e^{n_{0} x_{i}}+e^{n_{i} x_{i}}}$

The equations above have interdeterminancy problem and need to be removed. This calls that we assumed that $\mathrm{n}_{0}$ in the denominator is zero i.e. $n_{o}=0$. Then, $e^{n X i}=1$, hence

$\operatorname{Pr} o b\left(Y_{i}=j\right)=\frac{e^{n_{j} x_{i}}}{1+e^{n_{i} x_{i}}}$

$\operatorname{Pr} o b\left(Y_{i}=j\right)=\frac{e^{n_{j} x_{i}}}{1+n^{2} e^{n_{k} x_{i}}}$

Then, the probability of being users $(j=0$ or 1) is:

$\operatorname{Prob}\left(\mathrm{Y}_{\mathrm{i}}=0\right)=\frac{1}{1+\sum_{k=1}^{2} e \beta_{k} X_{i}}$
$\operatorname{Prob}\left(\mathrm{Y}_{\mathrm{i}}=1\right)=\frac{e \beta_{1 X i}}{1+\sum_{k=1}^{2} e \beta_{k} X_{i}}$

Where $\beta_{\mathrm{j}}$ is a vector of parameters that relates the explanatory variable $X_{i}$ to the probability.

The variables for the logit analysis are:

$\mathrm{Y}=$ Usage of improved storage techniques which is 1 if users and 0 if non- users

$X_{1}=$ Number of years of formal education of household head

$\mathrm{X}_{2}=$ Dummy variable for where the household head accept the challenge that pests are threat to the stored sorghum $=1$ or 0 otherwise $\mathrm{X}_{3}=$ Household size in number

$\mathrm{X}_{4}=$ Use of credit where Yes $=1$ and 0 otherwise. 


\section{RESULTS AND DISCUSSION}

\section{Socio-economic characteristics of the Household Heads}

The age of the farming households' heads ranged between 30 and 75 years with an average of 46 years. About $6.0 \%$ of household heads were above 60 years. Over $93 \%$ of the households' heads in the study area were below 60 years of age. The implication is that these household heads are in their active ages and can therefore be more productive (Table $1)$.

Sex distribution varied appreciably as $6.9 \%$ and $93.1 \%$ of the household heads were females and males respectively. The average household size was 9 persons. Most (69.3\%) households were polygamous in nature. Polygamous nature of the people probably explains the large family size recorded in the area. Their availability reduces labour constraints faced during the peak of the farming season. Majority (47.4\%) of the household heads were predominantly involved in agricultural trading, while others were involved in farming, non-agricultural trading, and civil service as their secondary sources of livelihood. Most (57.5\%) farming household heads were literate with most of them having primary education $(29.4 \%)$ and this was followed by adult education (11.2\%). Given this level of literacy it is expected that information can be disseminated with ease among these households' heads. The households head's years of storage experience ranged between 5 and 30 years with an average of the average of 13.9 years. Households' heads storage experience is expected to have a considerable effect on their productive efficiency. Majority of the household heads (74.4\%) got their initial starting capital from personal savings.

\section{Storage Activities}

About $46.0 \%$ of the households employed both family and hired labour in the storage of their sorghum while $50 \%$ and $3.8 \%$ of the sampled household heads' depend on family and hired labour respectively (Table 2).

Store is very important in keeping agricultural

Table 1. Socio-economic characteristics of the household heads

\begin{tabular}{|c|c|c|}
\hline Variables & Frequency & Percentage \\
\hline \multicolumn{3}{|l|}{ i) Age } \\
\hline $21-40$ years & 42 & 26.3 \\
\hline $41-60$ years & 108 & 67.5 \\
\hline $61-80$ years & 10 & 06.2 \\
\hline Total & 160 & 100.0 \\
\hline \multicolumn{3}{|l|}{ ii) $\mathrm{Sex}$} \\
\hline Male & 149 & 93.1 \\
\hline Female & 11 & 06.9 \\
\hline Total & 160 & 100.0 \\
\hline \multicolumn{3}{|l|}{ iii) Marital Status } \\
\hline Married & 140 & 87.5 \\
\hline Single & 05 & 03.1 \\
\hline Widower/ Separated & 15 & 09.4 \\
\hline Total & 160 & 100. \\
\hline \multicolumn{3}{|l|}{ iv) Household Size } \\
\hline $1-5$ & 14 & 08.8 \\
\hline $6-10$ & 100 & 62.5 \\
\hline $11-15$ & 44 & 27.5 \\
\hline $16-20$ & 02 & 01.2 \\
\hline Total & 160 & 100.0 \\
\hline \multicolumn{3}{|l|}{ v) Education Status } \\
\hline No Formal Education & 68 & 42.5 \\
\hline Quranic Education & 14 & 8.80 \\
\hline Primary Education & 47 & 29.4 \\
\hline Secondary & 12 & 07.5 \\
\hline \multicolumn{3}{|l|}{ Education } \\
\hline Tertiary Education & 01 & 0.60 \\
\hline Adult Education & 18 & 11.2 \\
\hline Total & 160 & 100.0 \\
\hline \multicolumn{3}{|l|}{ vi) Storage Experience } \\
\hline $1-10$ & 42 & 26.2 \\
\hline $11-20$ & 102 & 63.8 \\
\hline $21-30$ & 16 & 10.0 \\
\hline Total & 160 & 100.0 \\
\hline \multicolumn{3}{|l|}{ vii)Source of Credit } \\
\hline Personal Income & 119 & 74.4 \\
\hline Cooperatives & 25 & 15.6 \\
\hline Banks & 16 & 10.0 \\
\hline Total & 160 & 100.0 \\
\hline
\end{tabular}


produce especially sorghum. Result shows that sorghum stores are mostly (45.6\%) inherited by the respondents. About $29 \%$ of the sampled households paid rents on their store

Table: 2 Storage activities of the respondents

\begin{tabular}{|c|c|c|}
\hline Activity & Frequency & Percentage \\
\hline \multicolumn{3}{|l|}{ i) Source of Labour } \\
\hline Family Labour & 80 & 50.0 \\
\hline Hired Labour & 6 & 3.80 \\
\hline Family and Hired Labour & 74 & 46.2 \\
\hline Total & 160 & 100.0 \\
\hline \multicolumn{3}{|l|}{ ii) Store acquisition } \\
\hline Inherited & 73 & 45.6 \\
\hline Rented & 47 & 29.4 \\
\hline Owned & 40 & 25.0 \\
\hline Total & 160 & 100.0 \\
\hline \multicolumn{3}{|l|}{ iii) Agrochemical Used } \\
\hline Actellic Liquid & 52 & 32.5 \\
\hline Actellic Dust & 27 & 16.9 \\
\hline Phostoxin & 33 & 20.6 \\
\hline Not Applicable & 48 & 30.0 \\
\hline Total & 160 & 100.0 \\
\hline \multicolumn{3}{|c|}{ iv) Storage Techniques } \\
\hline Earthen Pot & 3 & 1.9 \\
\hline Jute Bag & 8 & 5.0 \\
\hline Gourd & 1 & 0.6 \\
\hline Raised Platform & 11 & 6.9 \\
\hline Drum & 13 & 8.1 \\
\hline Crib & 53 & 33.1 \\
\hline Rhumbus & 15 & 9.4 \\
\hline Sacks/Bags & 80 & 50.0 \\
\hline Silo & 1 & 0.6 \\
\hline Total & 160 & 100.0 \\
\hline \multicolumn{3}{|l|}{ v) Extent of adoption } \\
\hline \multicolumn{3}{|l|}{ Improved Storage } \\
\hline \multicolumn{3}{|l|}{ Techniques } \\
\hline Warehouse & 31 & \\
\hline Moditied Mud & 51 & \\
\hline \multicolumn{3}{|l|}{ Rhumbus } \\
\hline \multicolumn{3}{|l|}{ Ventilated Crib } \\
\hline \multicolumn{3}{|l|}{ Silo of varying sizes } \\
\hline Modified Oil Drums & & \\
\hline
\end{tabular}

Source: Field survey 2011/2012

Note: Also the extent adoption of improved storage techniques were not in percentages because there are multiple responses and this made them to incur extra cost compared to those who owned or inherited their stores. Most (32.5\%) respondents used Actellic liquid to prevent pest infestation, followed by phostoxin tablet $(20.6 \%)$. Thirty percent of the respondents did not use agro-chemicals at all. The table revealed that the use of bags or sacks for sorghum storage is common in the area. Half of the respondents used sacks to store their sorghum. The use of silos was least $(0.6 \%)$ used in the study area. On the whole, $23 \%$ of the sampled respondents have adopted improved storage techniques.

\section{Determinants of the usage of improved storage techniques}

The drivers of the usage of improved storage technique among the sampled households are presented in Table 3.

The logistic model explains $48.32 \%$ of the total variation in adoption status of households. This implies that the variables in the regression analysis accounted for about 50\% of the households' decision to adopt improved storage facilities. The coefficient of educational status, household size and credit access with the t-values of $2.197,-3.075$ and 2.539 respectively were all found to be significant in explaining the variation in the usage of improved storage techniques. Educational status of household head is positive and significantly influenced usage of improved storage techniques at $10 \%$ level of probability. This implies that as the educational status of the household head increases, the adoption of improved storage facilities increases. This could be due to the fact that educated household head are generally able to follow the required guidelines and methods involved in the improved storage techniques. Household size is negative and significantly influenced adoption of improved storage techniques at $1 \%$ level of significance. This implies as the household size increases, the possibility that the household head would adopt improved storage tech- 
niques decreases. This is because the larger the household size the less they are able to purchase and adopt improved storage technique in the area. Access to credit facilities was significant and positively related to the adoption of improved storage techniques at $5 \%$ level of probability. This implies that the more the household heads have access to credit facilities, the higher the adoption of improved storage techniques.

\section{CONCLUSION AND RECOMMENDA- TIONS}

The respondents have an average age of 46 years with an average storage experience of 14 years. The agro chemicals mostly used by the respondents are Actellic liquid, Actellic dust and Phostoxin Tablet to prevent pest infestation and spoilage. Also, the study showed that the level of adoption of improved storage techniques in Kwara State is generally low. The study indicated that educational status of the household head; household size and credit access were the major drivers explaining the adoption of improved storage techniques in the study area. Policy should target at strengthening farming households towards having improved access to both formal and informal sources of credits. Policy aimed at reducing household size should also be vigorously pursued. This has the potential to increase the intensity and the usage of im- proved storage techniques among farming households in the study area to attain sustainable sorghum production.

\section{REFERENCES}

Ajibola OO and Daramola AM 1998 Development and Management of Storage Structures for Small and Medium Scale Farmers". NSPRI, pp103-105.

Appert J 1997 The Storage of Food Grains and Seed: Macmillan publisher Limited London p146.

Babatunde RO, Omotesho OA and Sholotan OS 2007 Socio-economic characteristics and food security status of farming households in Kwara State, North-Central Nigeria. Pakistan Journal of Nutrition, 6, 49-58.

Babcock BA, Chaherli NM and Lakshminarayan PG 1995 Programme Participation and Farm-Level Adoption of Conservation Tillage: Estimates from a Multinomial Logit Model. Working Paper 95WP136, Centre for Agricultural and Rural Development, Iowa State University, Ames, Iowa.

Dike MC 1994 An Annotated Check List and Identification of Major Storage Pests in Nigeria. Samaru Miscellaneous Paper, $p$ 130.

Evans JD 2007 The Complete Real Estate Encyclopedia, The McGraw-Hill Companies, Inc.

\section{Table: 3 Logit regression analysis of households heads' use of improved storage techniques}

\begin{tabular}{lllll}
\hline Variables & Coefficients & Std Error & t-value & $\mathrm{P}[|\mathrm{Z}|>\mathrm{z}]$ \\
\hline Constant & $2.377^{* * *}$ & 0.714 & 3.329 & 0.002 \\
Educational Status $\left(\mathrm{X}_{1}\right)$ & $0.134^{*}$ & 0.061 & 2.197 & 0.030 \\
Pest Threat $\left(\mathrm{X}_{2}\right)$ & -0.304 & 0.479 & -0.635 & 0.526 \\
Household Size $\left(\mathrm{X}_{3}\right)$ & $-0.206^{* * *}$ & 0.067 & -3.075 & 0.002 \\
Credit Access $\left(\mathrm{X}_{4}\right)$ & $1.191 * *$ & 0.469 & 2.539 & 0.011 \\
\hline
\end{tabular}

Source: Data Analysis, 2012. *** parameter significant at 1\%,** parameter significant at 5\%, $*$ parameter significant at $10 \%$ 
Kader AA 2002 Postharvest technology of horticultural crops. 3rd ed. Univ. Calif. Agr. Nat. Resources, Oakland, Publ. 3311.

Kitinoja L and Gorny JR 1999 Postharvest technology for small-scale produce marketers: economic opportunities, quality and food safety. Univ. Calif. Postharvest Hort. Series No. 21.

Kumar R and Okoronkwo NO 1991 Effectiveness of Plant Oils on Cereals in Storage".

Journal of Insects Science and its Application, 12: 77-85.

Kwara State Dairy 2002 Kwara State Ministry of Information.

Maddala GS 1990 Limited Dependent and Quantitative Variables in Econometrics. Cambridge: Cambridge University Press. pp 21-65.

Okpeke LK 2006 Essentials of Crop Farming. Publihed by Spectrum Books Limited, Spectrum House Ring Road Ibadan, Nigeria. PMB 5612, p 165.

Ojo SK 2000 Sorghum in West Africa. In: Sorghum and Millets. Commodity and Research Environments, ICRISAT, India.

Sharma HC and Nwanze KF 1997 Insect Pest of Sorghum': Biology, Extent of Losses and Economic. Threshed Plant Research (Eds), pp 9-23.

Singh SR 2000 Insect Pests of Tropical Food Cereals. Chichester wilky p 451.

Singh SR, Singh BB, Jackai LEN and Ntare BR 1997 Advances in Sorghum Research. International Institute of Tropical Agriculture (IITA), Ibadan, Nigeria.

Werder J and Manzo SK 2002 Sorghum, millet diseases in Western African. A Second World Review, pp 109-114. 